\title{
Effects of extruding wheat dried distillers grains with solubles with peas or canola meal on ruminal fermentation, microbial protein synthesis, nutrient digestion, and milk production in dairy cows
}

\author{
R. M. Claassen, D. A. Christensen, and T. Mutsvangwa ${ }^{1}$ \\ Department of Animal and Poultry Science, University of Saskatchewan, Saskatoon, SK, Canada, S7N 5A8
}

\begin{abstract}
Our objective was to examine the effects of feeding coextruded and nonextruded supplements consisting of wheat dried distillers grains with solubles with peas (WDDGS-peas) or canola meal (WDDGS-CM) on ruminal fermentation, omasal flow, and production performance in Holstein cows. Eight cows (4 ruminally cannulated) were used in a replicated $4 \times 4$ Latin square with 28 -d periods and a $2 \times 2$ factorial arrangement of dietary treatments. Dietary treatments were coextruded or nonextruded mixtures of WDDGS-peas and WDDGS-CM that were included in total mixed rations at $15.1 \%$ [dry matter (DM) basis]. Diet had no effect on DM intake. Milk yield was greater in cows fed coextruded diets compared with those fed nonextruded diets. Milk fat content was greater in cows fed nonextruded diets compared with those fed coextruded diets, but milk fat yield was greater in cows fed coextruded diets compared with those fed nonextruded diets. Milk yield tended to be greater and milk protein yield was greater in cows fed WDDGS-peas compared with those fed WDDGS-CM. Cows fed nonextruded diets had a greater milk urea- $\mathrm{N}$ concentration compared with those fed coextruded diets. Cows fed coextruded diets had greater ruminal digestion of DM and tended to have greater ruminal digestion of organic matter compared with those fed nonextruded diets. Total-tract digestibilities of organic matter, crude protein, ether extract, and starch were greater, whereas that of acid detergent fiber and neutral detergent fiber tended to be greater in cows fed coextruded compared with those fed nonextruded diets. Total-tract digestibility of ether extract was lower whereas that of starch was greater and that of crude protein tended to be greater in cows fed WDDGS-peas compared with those fed WDDGS-CM. Total $\mathrm{N}$ excretion and milk $\mathrm{N}$ efficiency were unaffected
\end{abstract}

Received December 22, 2015.

Accepted June 7, 2016.

${ }^{1}$ Corresponding author: tim.mutsvan@usask.ca by diet. Ruminal $\mathrm{NH}_{3}-\mathrm{N}$ concentration tended to be greater in cows fed WDDGS-CM compared with those fed WDDGS-peas. Ruminal propionate concentration was greater whereas plasma urea- $\mathrm{N}$ concentration tended to be lower in cows fed coextruded compared with those fed nonextruded diets. Plasma glucose concentration was greater in cows fed diets containing WDDGS-CM compared with those fed diets containing WDDGS-peas, but the difference in plasma glucose concentration between WDDGS-CM and WDDGSpeas was greater in cows fed coextruded diets compared with those fed nonextruded diets. In summary, feeding coextruded compared with nonextruded supplements or WDDGS-peas compared WDDGS-CM increased yields of milk, fat, and protein.

Key words: dairy cow, dried distillers grains with solubles, peas, canola meal

\section{INTRODUCTION}

Traditionally, ethanol production in western Canada has used wheat as the major feedstock. Recently, the rapid expansion of ethanol production has resulted in an abundant supply of wheat dried distillers grains with solubles (WDDGS) that can be used as a protein source for dairy cows. Perusal of the literature indicates that several recent studies (Abdelqader and Oba, 2012; Chibisa et al., 2012; Chibisa and Mutsvangwa, 2013; Maxin et al., 2013a) have demonstrated that WDDGS can be used as a replacement for traditional protein supplements such as canola meal (CM) without compromising milk production. In western Canada and parts of the United States, dairy cow diets are typically formulated to contain CM as the major source of protein because it is readily available and is a highquality protein supplement (Hickling, 2008; Mulrooney et al., 2009). It is well established that major differences exist in the chemical compositions and ruminal degradabilities of CM and WDDGS (Boila and Ingalls, 1994). When compared with CM, the available data indicates that WDDGS is greater in CP content (43.6 vs. 39.5\%; Boila and Ingalls, 1994), but is lower in Met 
(1.75 vs. $2.68 \mathrm{~g} / 16 \mathrm{~g}$ of $\mathrm{N}$ ) and, particularly, Lys (2.04 vs. $5.30 \mathrm{~g} / 16 \mathrm{~g}$ of N) contents (Boila and Ingalls, 1994). Also, ruminal $\mathrm{N}$ degradability (as assessed using the in situ technique) of WDDGS was much lower (36.5 vs. 63.4\%) when compared with CM (Boila and Ingalls, 1994). In vivo measurements using the omasal sampling technique also indicated that RDP supply decreased whereas RUP supply increased when WDDGS replaced CM in lactating cow diets (Chibisa et al., 2012). Peas (Pisum sativum) contain relatively high levels of $\mathrm{CP}$ (24 to 28\%) and starch (48\%; Petit et al., 1997; NRC, 2001), so they have been used as a cheaper replacement for more expensive protein and energy sources in diets for lactating dairy cows without negatively affecting milk yield and composition (Petit et al., 1997; Khorasani et al., 2001; Masoero et al., 2006). When compared with WDDGS, peas contain less CP, which is more ruminally degradable ( $78 \% \mathrm{RDP}$ as a percent of $\mathrm{CP}$ ); however, peas contain greater levels of Lys compared with WDDGS (NRC, 2001). These differences in chemical composition and ruminal degradability among WDDGS, CM, and peas causes one to consider that judicious combinations of WDDGS with CM and WDDGS with peas would supply sufficient amounts of RDP to meet microbial $\mathrm{N}$ requirements, and also providing adequate amounts of RUP with a good AA (Lys and Met) balance to optimize milk production in high-producing dairy cows.

Altering the physical structure of proteinaceous feedstuffs through heat processing methods such as extrusion may help to protect dietary protein from ruminal degradation, thus increasing the postruminal supply of digestible RUP that might benefit high-producing dairy cows (NRC, 2001). The exposure of proteinaceous feedstuffs to heat processing reduces ruminal protein degradation through protein denaturation and the formation of complexes (e.g., protein-protein linkages) that are resistant to ruminal degradation (NRC, 2001). Numerous studies (Focant et al., 1990; Walhain et al., 1992; Gonthier et al., 2004) have reported decreased ruminal protein degradation when proteinaceous feedstuffs such as flaxseed and peas have been subjected to extrusion processing. Because of the differences in chemical composition and ruminal degradability among WDDGS, CM, and peas indicated previously, the coextrusion of judicious combinations of WDDGS with CM and WDDGS with peas might be of benefit in terms of improving ruminal $\mathrm{N}$ utilization and postruminal RUP supply. To our knowledge, comparative studies do not exist that have investigated the effects of feeding nonextruded or coextruded combinations of WDDGS-CM and WDDGS-peas on ruminal digestion, $\mathrm{N}$ utilization, and production performance in dairy cows. Therefore, our specific objective was to determine the interactive effects of feeding nonextruded or coextruded mixtures of WDDGS-CM and WDDGS-peas on ruminal fermentation characteristics, microbial protein production, omasal nutrient flow, and production performance of high-producing dairy cows.

\section{MATERIALS AND METHODS}

\section{Animals and Experimental}

Eight multiparous lactating Holstein cows $(712 \pm 54$ $\mathrm{kg}$ of BW; $90 \pm 31$ DIM at the beginning of the experiment) housed in individual tiestalls at the University of Saskatchewan Greenbrae Dairy Research Facility were used in this study. The experimental design was a replicated $4 \times 4$ Latin square design with a $2 \times 2$ factorial arrangement of dietary treatments. Each experimental period was $28 \mathrm{~d}$ in length, consisting of $20 \mathrm{~d}$ of diet adaptation and $8 \mathrm{~d}$ of sample and data collection. Four cows in 1 Latin square were ruminally cannulated to facilitate ruminal and omasal sampling. The University of Saskatchewan Animal Care Committee approved the use of cows for this experiment (UCACS Protocol No. 20040048), and they were cared for in accordance with the Canadian Council on Animal Care (1993) regulations.

\section{Dietary Treatments and Feeding Management}

Experimental treatments were combinations of 2 protein supplements fed in nonextruded and coextruded forms as follows: (1) nonextruded WDDGS-peas; (2) coextruded WDDGS-peas; (3) nonextruded WDDGSCM; and (4) coextruded WDDGS-CM. Extruded diets were processed at $\mathrm{O}$ and $\mathrm{T}$ Farms (Regina, SK, Canada) using a Insta-Pro International 2500 series extruder (Des Moines, IA) with a custom 5-hole (5/16inch hole) nose cone. Extruding temperatures for coextruded WDDGS-peas and WDDGS-CM supplements were $161^{\circ} \mathrm{C}\left(\right.$ range $\left.=131-184^{\circ} \mathrm{C}\right)$ and $160^{\circ} \mathrm{C}$ (range $=$ $142-179^{\circ} \mathrm{C}$ ), respectively. Single batches of WDDGS, $\mathrm{CM}$, and peas were used for nonextruded and coextruded supplements for the entire study. The chemical compositions of the nonextruded and coextruded WDDGS-peas and WDDGS-CM supplements are presented in Table 1. The experimental diets were fed as TMR and contained $7.9 \%$ WDDGS and $7.2 \% \mathrm{CM}$ or peas (Table 2). The forage-to-concentrate ratio of the TMR was 47:53, with the forage component of the TMR being a mixture of barley silage (approximately $68 \%$ on a DM basis) and chopped alfalfa hay (32\%; Table 2). By design, the inclusion levels of various protein supple- 
Table 1. Chemical composition of the extruded and nonextruded supplements that were fed to dairy cows

\begin{tabular}{lccccc}
\hline & \multicolumn{2}{c}{ Coextruded } & & \multicolumn{2}{c}{ Nonextruded } \\
\cline { 2 - 3 } \cline { 5 - 6 } Item & WDDGS-Peas & WDDGS-CM & & WDDGS-Peas & WDDGS-CM \\
\hline DM, \% & 90.9 & 90.8 & & 89.9 & 91.2 \\
OM, \% of DM & 95.6 & 93.9 & & 95.9 & 93.9 \\
CP, \% of DM & 30.8 & 39.2 & & 31.3 & 39.4 \\
ADF, \% of DM & 8.6 & 14.5 & & 7.8 & 14.5 \\
NDF, \% of DM & 20.4 & 31.7 & & 20.9 & 31.5 \\
Ether extract, \% of DM & 6.0 & 5.8 & & 7.1 & 7.1 \\
Starch, \% of DM & 21.5 & 2.6 & & 21.0 & 1.9 \\
\hline
\end{tabular}

${ }^{1}$ WDDGS-Peas $=$ wheat dried distillers grains with solubles plus peas; WDDS-CM $=$ wheat dried distillers grains with solubles plus canola meal.

ments were similar for coextruded versus nonextruded WDDGS-peas or WDDGS-CM; however, because the WDDGS-peas and WDDGS-CM supplements differed in their $\mathrm{CP}$ contents, it was necessary to include variable amounts of soybean meal and corn gluten meal to make diets containing WDDGS-peas or WDDGS-
CM isonitrogenous. Even though the inclusion levels of soybean meal and corn gluten meal across diets were different, it should be noted that all diets contained the same supplemental sources of protein which would provide similar profiles of AA. Cows were fed twice daily at 0900 and $1600 \mathrm{~h}$ for ad libitum intake.

Table 2. Feed ingredient and chemical compositions of the 4 experimental diets ${ }^{1}$

\begin{tabular}{|c|c|c|c|c|}
\hline \multirow[b]{2}{*}{ Item } & \multicolumn{2}{|c|}{ Coextruded } & \multicolumn{2}{|c|}{ Nonextruded } \\
\hline & WDDGS-Peas & WDDGS-CM & WDDGS-Peas & WDDGS-CM \\
\hline \multicolumn{5}{|l|}{ Ingredient, $\%$ of DM } \\
\hline Barley silage & 31.6 & 31.8 & 31.6 & 31.8 \\
\hline Alfalfa hay & 14.6 & 15.1 & 14.6 & 15.1 \\
\hline Barley grain & 30.0 & 31.8 & 30.0 & 31.8 \\
\hline WDDGS & 7.9 & 7.9 & 7.9 & 7.9 \\
\hline Canola seed & 0.8 & 0.8 & 0.8 & 0.8 \\
\hline Pea grain & 7.2 & - & 7.2 & - \\
\hline Canola meal & - & 7.2 & - & 7.2 \\
\hline Molasses & 0.2 & 0.2 & 0.2 & 0.2 \\
\hline Corn gluten meal & 1.98 & 0.20 & 1.98 & 0.20 \\
\hline Soybean meal & 1.09 & 0.08 & 1.09 & 0.08 \\
\hline Vitamin premix ${ }^{2}$ & 1.8 & 1.8 & 1.8 & 1.8 \\
\hline Limestone & 0.05 & 0.05 & 0.05 & 0.05 \\
\hline Rumen-protected fat source ${ }^{3}$ & 1.58 & 1.79 & 1.58 & 1.79 \\
\hline Salt & 0.20 & 0.20 & 0.20 & 0.20 \\
\hline Sodium bicarbonate & 0.87 & 0.88 & 0.87 & 0.88 \\
\hline Potassium-magnesium sulfate ${ }^{4}$ & 0.16 & 0.16 & 0.16 & 0.16 \\
\hline \multicolumn{5}{|l|}{ Chemical composition } \\
\hline $\mathrm{DM}, \%$ & 57.7 & 57.7 & 57.5 & 57.3 \\
\hline $\mathrm{OM}, \%$ of $\mathrm{DM}$ & 92.1 & 91.8 & 92.0 & 91.6 \\
\hline $\mathrm{CP}, \%$ of $\mathrm{DM}$ & 17.1 & 17.0 & 17.3 & 17.2 \\
\hline $\mathrm{ADF}, \%$ of $\mathrm{DM}$ & 14.7 & 15.6 & 14.2 & 15.2 \\
\hline $\mathrm{NDF}, \%$ of DM & 27.4 & 29.1 & 26.6 & 28.5 \\
\hline Ether extract, \% of DM & 3.9 & 4.2 & 3.9 & 4.2 \\
\hline Starch, $\%$ of DM & 23.3 & 21.3 & 22.2 & 21.1 \\
\hline $\mathrm{NE}_{\mathrm{L}},{ }^{5} \mathrm{Mcal} / \mathrm{kg}$ of DM & 1.68 & 1.65 & 1.68 & 1.65 \\
\hline
\end{tabular}

${ }^{1}$ WDDGS-Peas $=$ wheat dried distillers grains with solubles plus peas; WDDS-CM $=$ wheat dried distillers grains with solubles plus canola meal.

${ }^{2}$ Contained (per kg of premix; DM basis): 330,000 IU of vitamin A, 60,000 IU of vitamin D, $1000 \mathrm{IU}$ of vitamin E, $16 \% \mathrm{Ca}, 8.5 \% \mathrm{P}, 6.3 \% \mathrm{Na}, 4.5 \% \mathrm{Mg}, 2,100 \mathrm{mg}$ of $\mathrm{Zn}, 1,500 \mathrm{mg}$ of $\mathrm{Mn}, 535 \mathrm{mg}$ of $\mathrm{Cu}, 12 \mathrm{mg}$ of Se, $45 \mathrm{mg}$ of I.

${ }^{3}$ Golden Flake (Nutrition Trading International Ltd., Warwickshire, UK), which is a ruminally-protected fat of palm fatty acids from palm oil containing $45 \%$ C16 and 48\% C18 fatty acids.

${ }^{4}$ Dynamate (The Mosaic Company, Plymouth, MN), which contains $18.5 \% \mathrm{~K}, 22.3 \% \mathrm{~S}$, and $11.6 \% \mathrm{Mg}$.

${ }^{5}$ Calculated from CPM Dairy Ration Analyzer v3.0.0. 


\section{Data and Sample Collection}

Individual feed intakes for all 8 cows were recorded daily during the 8-d collection period. Samples of TMR, nonextruded and coextruded WDDGS-peas and WDDGS-CM supplements, and orts were collected on d 25, 26, and 27 of each experimental period. Samples of TMR and orts were stored at $-20^{\circ} \mathrm{C}$, whereas those of nonextruded and coextruded WDDGS-peas and WDDGS-CM supplements were stored at room temperature pending chemical analysis. Experimental cows were milked 3 times daily at 0430, 1230, and $1900 \mathrm{~h}$. Milk samples were taken at each milking on d 25, 26, and 27. Milk samples were preserved with 2-bromo2-nitropropane-1-2-diol, pooled proportionally based on milk yield on a daily basis, and stored at $4^{\circ} \mathrm{C}$. After the 3-d milk sampling period, pooled milk samples were sent to the CanWest DHI Central Milk Testing Laboratory (Edmonton, AB, Canada) for analysis.

The 4 ruminally cannulated cows were used in a metabolism trial to study diet effects on ruminal fermentation and omasal nutrient flow. To quantify omasal digesta flow, indigestible NDF (iNDF; Reynal et al., 2005), $\mathrm{Yb}$ [as $\mathrm{YbCl}_{3} \cdot 6 \mathrm{H}_{2} \mathrm{O}$ (obtained from VWR International, Mississauga, ON, Canada); Siddons et al., 1985], and Cr (as Cr-EDTA; Udén et al., 1980) were used as digesta markers for the large particle $(\mathbf{L P})$, small particle (SP), and fluid (FP) phases, respectively. The Cr-EDTA complex was prepared using EDTA, $\mathrm{CrCl}_{3} \cdot 6 \mathrm{H}_{2} \mathrm{O}$, and $\mathrm{CaCl}_{2}$ (VWR International) according to the method described by Binnerts et al. (1968). To quantify ruminal microbial protein production, ${ }^{15} \mathrm{~N}$ [infused as $\left({ }^{15} \mathrm{NH}_{4}\right)_{2} \mathrm{SO}_{4} ; 10$ atom percent excess (APE) ${ }^{15} \mathrm{~N}$; Cambridge Isotope Laboratories, Andover, MA] was used as a microbial marker (Reynal et al., 2005). Prior to the initiation of marker infusions on d 14 of each experimental period, a 400-mL sample of omasal digesta was taken from each cow to determine background concentrations of $\mathrm{Cr}$ and $\mathrm{Yb}$, and ${ }^{15} \mathrm{~N}$ natural abundance. Thereafter, a 1-L priming dose containing one-half of the daily doses of $\mathrm{Yb}, \mathrm{Cr}$, and ${ }^{15} \mathrm{~N}$ was administered into the rumen via the ruminal cannula before the initiation of the continuous marker infusions. Markers dissolved in $2 \mathrm{~L}$ of distilled water were infused at daily rates of $3.35 \mathrm{~g}$ of $\mathrm{Yb}$ (Brito et al., 2006), 2.77 $\mathrm{g}$ of $\mathrm{Cr}$ (Binnerts et al., 1968), and $0.22 \mathrm{~g}$ of ${ }^{15} \mathrm{~N}$ (Brito et al., 2006) for $8 \mathrm{~d}$ using a Watson and Marlow Model 205U peristaltic pump (Cornwall, UK). The omasal sampling technique as described by Huhtanen et al. (1997) was used to collect omasal digesta. Omasal digesta samples were collected at 0900, 1500, and $2100 \mathrm{~h}$ on d 20;0000, 0300, 1200, and $1800 \mathrm{~h}$ on d 21; and 0600 $\mathrm{h}$ on d 22 to represent a 24 -h feeding cycle. At each sampling, a 600-mL sample of omasal digesta was col- lected. The omasal digesta was thoroughly mixed and divided into 3 subsamples of 100, 200, and $300 \mathrm{~mL}$. The 300 -mL subsamples were pooled per cow per period to produce a 2.4-L composite sample that was stored at $-20^{\circ} \mathrm{C}$. The $200-\mathrm{mL}$ subsamples were held on ice and pooled over 2 consecutive samplings to yield a $400-\mathrm{mL}$ composite sample that was used for the isolation of particle-associated (PAB) and fluid-associated (FAB) bacteria using filtration and differential centrifugation (Brito et al., 2009). After isolation, the PAB and FAB pellets were pooled per cow per period and stored at $-20^{\circ} \mathrm{C}$. The $100-\mathrm{mL}$ subsamples were pooled per cow per period and stored at $-20^{\circ} \mathrm{C}$ as spare samples.

Total urine and fecal collections were conducted for $4 \mathrm{~d}$ (d 24 to 28 ) using the 4 ruminally cannulated cows. On d 23, cows were fitted with indwelling Bardex Foley bladder catheters (26 Fr, 75-mL ribbed balloon, lubricious-coated; C. R. Bard Inc., Covington, GA). Just before the initiation of total collections at 0900 $\mathrm{h}$ on d 24, bladder catheters were connected to urine collection tubing. Urine was collected into 20-L Carboy polyethylene containers that contained $150 \mathrm{~mL}$ of concentrated $\mathrm{HCl}$. The addition of concentrated $\mathrm{HCl}$ was necessary to acidify the urine so as to prevent $\mathrm{NH}_{3}-\mathrm{N}$ volatilization and microbial degradation. Between d 25 and 28 at $0900 \mathrm{~h}$, the daily urine output for each cow was weighed, mixed thoroughly, and a $5 \%$ subsample was taken. Urine subsamples were pooled for each cow during each collection period and stored at $-20^{\circ} \mathrm{C}$ until analyzed for total N. At the same time as urine collections, feces were collected into large steel trays that were positioned over the gutter behind each stall. Daily fecal output for each cow was determined by weighing. Feces were then mixed thoroughly using a shovel and a $2.5 \%$ subsample was taken and stored at $-20^{\circ} \mathrm{C}$ for later chemical analysis.

Blood was collected from the coccygeal vein of all 8 cows at $1100 \mathrm{~h}$ on d 25 using a 10-mL lithium heparincoated Vacutainer (Becton Dickinson, Franklin Lakes, $\mathrm{NJ}$ ). Blood was centrifuged at $1,500 \times g$ at $4^{\circ} \mathrm{C}$ for 15 min to obtain plasma, which was then stored at $-20^{\circ} \mathrm{C}$. Starting on d 27, $250 \mathrm{~mL}$ of ruminal digesta samples were collected from the cranial-ventral, caudal-ventral, ventral, and cranial-dorsal rumen through the cannula at $0900,1200,1500,1800,2100,0000,0300$, and 0600 $\mathrm{h}$ to represent a 24 -h feeding cycle. Ruminal fluid was obtained by straining ruminal digesta through 4 layers of cheesecloth. Ruminal fluid $\mathrm{pH}$ was measured immediately using a Model 265A portable $\mathrm{pH}$ meter (Orion Research Inc., Beverly, MA). A 10-mL ruminal fluid subsample was mixed with $2 \mathrm{~mL}$ of chilled $25 \%$ (wt/vol) meta-phosphoric acid $\left(\mathrm{H}_{2} \mathrm{PO}_{4}\right)$ and stored at $-20^{\circ} \mathrm{C}$ for later determination of short-chain fatty acid (SCFA) concentrations. A second 10-mL sample 
was mixed with $2 \mathrm{~mL}$ of $1 \%$ sulfuric acid $\left(\mathrm{H}_{2} \mathrm{SO}_{4}\right)$ and stored at $-20^{\circ} \mathrm{C}$ for later determination of $\mathrm{NH}_{3}-\mathrm{N}$ concentrations.

\section{Sample Analyses}

At the end of the experiment, frozen TMR, orts, and fecal samples were thawed overnight at room temperature and dried at $55^{\circ} \mathrm{C}$ for $72 \mathrm{~h}$. Samples of dried TMR, orts, feces, and nonextruded and coextruded WDDGSpeas and WDDGS-CM supplements were then ground through a 1-mm screen using a Christy-Norris mill (Christy and Norris Ltd., Chelmsford, UK). Ground TMR, orts, and fecal samples were then composited per cow in each experimental period. Ground samples of nonextruded and coextruded WDDGS-peas and WDDGS-CM supplements were composited per period. Composited samples of TMR, orts, feces, and nonextruded and coextruded WDDGS-peas and WDDGSCM supplements were analyzed for DM (AOAC, 1990; method 930.15), OM (AOAC, 1990; method 942.05), $\mathrm{CP}$ using the macro-Kjeldahl procedure (AOAC, 1990; method 976.05), ether extract (EE; AOAC, 1990; method 920.39), total starch (Megazyme Total Starch K-TSTA kit, DMSO method 996.11; AOAC 1990), and ADF and NDF (Van Soest et al., 1991). Amylase and sodium sulfite were used for NDF determination.

Pooled milk samples were analyzed for fat, CP, lactose and MUN using infrared spectroscopy (MilkoScan 605, Foss Electric, Hillerød, Denmark; AOAC, 1990; method 972.16). Frozen urine and plasma samples were thawed overnight at room temperature. Urine samples were analyzed for total $\mathrm{N}$ using the macro-Kjeldahl procedure (AOAC, 1990; method 976.05). Plasma samples were analyzed for glucose using a single-reagent glucose oxidase commercial kit (Stanbio Glucose LiquiColor Kit, Procedure No. 1070; Stanbio Laboratory, Boerne, TX) that is based on a technique developed by Trinder (1969). Urine and plasma samples were also analyzed for urea-N using the diacetyl monoxime method of Marsh et al. (1957) using a commercial kit (Stanbio Urea Nitrogen Kit, Procedure No. 0580; Stanbio Laboratory).

Background ${ }^{15} \mathrm{~N}$ omasal digesta samples and pooled $\mathrm{PAB}$ and FAB pellets were freeze-dried and ground with a mortar and pestle before analysis for $\mathrm{OM}$ as previously described. For analysis of NAN and ${ }^{15} \mathrm{~N}$ enrichment of ${ }^{15} \mathrm{~N}$ natural abundance, $\mathrm{FAB}$, and $\mathrm{PAB}$ samples, $\mathrm{NH}_{3}-\mathrm{N}$ was volatilized using a modified procedure from Reynal et al. (2005). Briefly, a 2-mg sample (containing approximately $150 \mu \mathrm{g}$ of $\mathrm{N}$ ) was weighed into 5- $\times$ 9-mm tin capsules (Elemental Microanalysis Limited, Okehampton, UK), treated with $50 \mu \mathrm{L}$ of 72 $\mathrm{m} M \mathrm{~K}_{2} \mathrm{CO}_{3}$, and then dried in a forced-air oven at $60^{\circ} \mathrm{C}$ for $24 \mathrm{~h}$. Samples were then analyzed for ${ }^{15} \mathrm{~N}$ enrichment by combustion to $\mathrm{N}_{2}$ gas in an elemental analyzer and continuous flow isotope ratio-mass spectrometry.

The pooled 2.4-L omasal digesta samples were thawed overnight at room temperature and then separated into 3 phases (Reynal et al., 2005). Briefly, omasal digesta was strained through one layer of cheesecloth. The filtrand retained on the cheesecloth was kept as the LP. The filtrate was then centrifuged at 1,000 $\times g$ for $5 \mathrm{~min}$ at $5^{\circ} \mathrm{C}$, and the resultant pellet was the $\mathrm{SP}$ whereas the supernatant was the FP. The LP, SP, and FP were freeze-dried and then ground through a 1-mm screen (LP; Christy-Norris mill) or with a mortar and pestle (FP and SP). The content of iNDF in TMR, SP, and LP samples was determined using a 12-d ruminal incubation procedure (Huhtanen et al. 1994) with 3-, $3.5-$, and 1.5 -g samples, respectively, in $6-\mu \mathrm{m}$ pore $5-\times$ 10-cm nylon bags (Ankom Technology, Macedon, NY). The incubated samples were analyzed for NDF using the procedure described previously. The LP, SP, and FP samples were combusted at $550^{\circ} \mathrm{C}$ for $8 \mathrm{~h}$ in a muffle furnace (AOAC, 1990) and then digested with nitric acid as described by Vicente et al. (2004). Digested LP, $\mathrm{SP}$, and FP samples were analyzed for $\mathrm{Yb}$ concentration using atomic emission (Varian Spectra 220, Varian, Mulgrave, Australia) and $\mathrm{Cr}$ concentration using atomic absorption (Perkin Elmer 2300, Perkin-Elmer Corp., Norwalk, CT). Samples of the infusates that were obtained daily during infusions were also analyzed for $\mathrm{Cr}$ and $\mathrm{Yb}$ concentrations. The concentrations of iNDF (LP marker), Yb (SP marker), and Cr (FP marker) in their respective phases were used to reconstitute the omasal true digesta (OTD) using the triple marker method (France and Siddons, 1986). Marker concentrations were also used to physically reconstitute a 2-g particle phase (PF) sample consisting of SP and LP. The reconstituted OTD was then analyzed for DM, $\mathrm{OM}, \mathrm{CP}$, total starch, ADF, and NDF using procedures described previously. The concentration of $\mathrm{NH}_{3}-\mathrm{N}$ in OTD was determined by adding $10 \mathrm{~mL}$ of $0.07 \mathrm{M}$ sodium citrate solution ( $\mathrm{pH} 2.2$ ) to a 0.5 -g sample that was then vortexed and placed in a forced-air oven at $39^{\circ} \mathrm{C}$ for $30 \mathrm{~min}$. The samples were centrifuged at $18,000 \times$ $g$ at $4^{\circ} \mathrm{C}$ for $15 \mathrm{~min}$ and the resulting supernatant was analyzed for $\mathrm{NH}_{3}-\mathrm{N}$ using the phenol-hypochlorite assay (Broderick and Kang, 1980). Samples of FP, PF, and OTD were prepared for ${ }^{15} \mathrm{~N}$ analysis by first volatizing $\mathrm{NH}_{3}$ in samples containing approximately $100 \mu \mathrm{g}$ of $\mathrm{N}$ (Brito et al., 2009). These samples were weighed into $5-\times 9-\mathrm{mm}$ tin capsules and $50 \mu \mathrm{L}$ of $72 \mathrm{mM} \mathrm{K}_{2} \mathrm{CO}_{3}$ was added to each capsule before incubation in a forced-air oven at $60^{\circ} \mathrm{C}$ for $24 \mathrm{~h}$. Enrichment of ${ }^{15} \mathrm{~N}$ in NAN of the 
samples was then measured by combustion to $\mathrm{N}_{2}$ gas in an elemental analyzer and continuous flow isotope ratio-mass spectrometry.

Thawed ruminal fluid samples previously acidified with $\mathrm{H}_{2} \mathrm{PO}_{4}$ were vortexed and then centrifuged at $3,655 \times g$ at $4^{\circ} \mathrm{C}$ for $15 \mathrm{~min}$. A $120-\mu \mathrm{L}$ subsample of the supernatant was mixed with $500 \mu \mathrm{L}$ of $1 \mathrm{mM}$ trimethyl acetic acid (used as an internal standard) and $880 \mu \mathrm{L}$ of acetonitrile in a microcentrifuge tube that was kept on ice. The mixture was then vortexed and centrifuged at $16,000 \times \mathrm{g}$ at $4^{\circ} \mathrm{C}$ for $5 \mathrm{~min}$. The supernatant was analyzed for SCFA using GC (Agilent 6890 Series Gas Chromatography System, Wilmington, DE) as described by Erwin et al. (1961). Thawed ruminal fluid samples previously acidified with $\mathrm{H}_{2} \mathrm{SO}_{4}$ were vortexed, centrifuged at $14,000 \times g$ at $4^{\circ} \mathrm{C}$ for 10 min, and analyzed for $\mathrm{NH}_{3}-\mathrm{N}$ concentration using the phenol-hypochlorite assay (Broderick and Kang, 1980).

\section{Calculations and Statistical Analyses}

Calculations of bacterial $\mathrm{N}$ yield using ${ }^{15} \mathrm{~N}$ as a microbial marker were conducted as described by Reynal et al. (2005). Briefly, the ${ }^{15} \mathrm{~N}$ enrichment (APE) in OTD, and FAB and PAB bacterial samples were calculated as ${ }^{15} \mathrm{~N}$-APE $={ }^{15} \mathrm{~N}$-atom $\%$ in sample $-{ }^{15} \mathrm{~N}$ atom $\%$ in ${ }^{15} \mathrm{NB}$ sample. Flows of FAB and PAB at the omasal canal were calculated as FP NAN flow $x$ $\left(\mathrm{FP}^{15} \mathrm{~N}\right.$ APE $\div$ FAB ${ }^{15} \mathrm{~N}$ APE) and PF NAN flow $\times$ $\left(\mathrm{PF}{ }^{15} \mathrm{~N}\right.$ APE $\div \mathrm{PAB}{ }^{15} \mathrm{~N}$ APE), respectively. Total bacterial NAN flow was calculated as FAB NAN flow + PAB NAN flow. The NAN content of OTD samples was calculated as total $\mathrm{N}$ minus ammonia $\mathrm{N}$. Omasal flows of other nutrients were calculated by multiplying DM flow by their concentration in OTD. Apparent ruminal digestion of nutrients was calculated as nutrient intake minus omasal flow of nutrient. Similarly, the flows of nonammonia nonmicrobial N (NANMN), RUP, and RDP at the omasal canal were calculated as described by Reynal et al. (2005) as: NANMN flow = total NAN flow - microbial NAN flow; RUP flow $=$ total $\mathrm{CP}$ flow - microbial CP flow; and RDP supply $=$ total $\mathrm{CP}$ intake - RUP flow.

All data ( $\mathrm{n}=4$ cows $)$ on ruminal and total-tract nutrient digestibilities, ruminal $\mathrm{N}$ utilization, microbial $\mathrm{N}$ synthesis, and omasal nutrient flows were analyzed as a $4 \times 4$ Latin square using the MIXED procedure of SAS (SAS Institute, 2004). The model that was used accounted for effects of period, cow, dietary treatment (i.e., source of dietary supplement and extrusion processing), and the source of dietary supplement by extrusion processing interaction. Period and dietary treatment were considered as fixed, whereas cow was considered as random. Data on ruminal $\mathrm{pH}$, and rumi- nal $\mathrm{NH}_{3}-\mathrm{N}$ and SCFA concentrations $(\mathrm{n}=4$ cows) were analyzed using the repeated measures option within the MIXED procedure of SAS Institute (2004). The model included period, source of dietary supplement, extrusion processing, hour, and interactions for source of dietary supplement by extrusion processing, source of dietary supplement by hour, extrusion processing by hour, and source of dietary supplement by extrusion processing by hour, which were considered as fixed effects. Cow was considered as a random effect. The Kenward-Roger option was used to estimate denominator degrees of freedom. The 9 covariance structures that were tested were: autoregressive 1 (AR [1]); compound symmetry (CS); heterogeneous autoregressive (ARH [1]); unstructured (UN); variance components (VC); Toeplitz (Toep); heterogeneous compound symmetry (CSH); heterogeneous Toeplitz (Toeph); and simple. The covariance structure with the smallest Akaike's information criterion values was selected (Littell et al., 2006). All data on production performance and plasma metabolites $(\mathrm{n}=$ 8 cows) were analyzed using the MIXED procedure of SAS (SAS Institute, 2004) for a replicated $4 \times 4$ Latin square design. The models included cow nested within square, square, period, dietary treatment (i.e., source of dietary supplement and extrusion processing), and the source of dietary supplement by extrusion processing interaction. Period, square, and dietary treatment were considered as fixed, whereas cow nested within square was considered as random. Treatment differences were considered significant when $P \leq 0.05$ and tendencies when $0.05<P \leq 0.10$. When we observed a significant interaction between the source of dietary supplement and extrusion processing, means were separated by Tukey's HSD test (SAS Institute, 2004).

\section{RESULTS}

\section{Dietary Characteristics}

The WDDGS-CM supplements contained numerically more CP and less starch compared with the WDDGSpeas supplements (Table 1), which is reflective of the differences in $\mathrm{CP}$ and starch contents of $\mathrm{CM}$ and peas. Also, the WDDGS-CM supplements contained numerically more ADF and NDF compared with the WDDGSpeas supplements, which can be attributed to the higher fiber content in CM compared with peas (NRC, 2001). As expected, the chemical compositions of nonextruded and coextruded supplements were similar because they contained similar ingredients in the same proportions, except that coextruded supplements contained slightly less ( -1 percentage unit) EE compared with the nonextruded supplements. This difference in EE contents of coextruded and nonextruded supplements 
Table 3. Dry matter intake, milk yield, and milk composition in cows fed the 4 experimental diets ${ }^{1}$

\begin{tabular}{|c|c|c|c|c|c|c|c|c|}
\hline \multirow[b]{2}{*}{ Item } & \multicolumn{2}{|c|}{ Coextruded $^{2}$} & \multicolumn{2}{|c|}{ Nonextruded $^{2}$} & \multirow[b]{2}{*}{ SEM } & \multicolumn{3}{|c|}{$P$-value ${ }^{3}$} \\
\hline & WDDGS-Peas & WDDGS-CM & WDDGS-Peas & WDDGS-CM & & $\begin{array}{l}\text { Source } \\
(\mathrm{S})\end{array}$ & $\begin{array}{l}\text { Extrusion } \\
\text { (E) }\end{array}$ & $\mathrm{S} \times \mathrm{E}$ \\
\hline Milk yield, $\mathrm{kg} / \mathrm{d}$ & 44.2 & 41.6 & 42.8 & 38.8 & 2.0 & 0.06 & 0.03 & 0.42 \\
\hline $3.5 \% \mathrm{FCM}^{4}{ }^{4} \mathrm{~kg} / \mathrm{d}$ & 43.7 & 42.0 & 42.6 & 39.9 & 1.7 & 0.17 & 0.03 & 0.38 \\
\hline Milk fat, $\%$ & 3.48 & 3.59 & 3.54 & 3.61 & 0.24 & 0.26 & 0.04 & 0.35 \\
\hline Milk fat yield, $\mathrm{kg} / \mathrm{d}$ & 1.53 & 1.47 & 1.49 & 1.40 & 0.06 & 0.17 & 0.03 & 0.38 \\
\hline Milk protein yield, $\mathrm{kg} / \mathrm{d}$ & 1.38 & 1.32 & 1.37 & 1.26 & 0.06 & 0.05 & 0.14 & 0.30 \\
\hline Milk lactose yield, $\mathrm{kg} / \mathrm{d}$ & 2.02 & 1.88 & 1.91 & 1.75 & 0.10 & 0.06 & 0.01 & 0.62 \\
\hline MUN, mg/dL & 15.1 & 14.8 & 15.5 & 16.0 & 0.8 & 0.80 & 0.01 & 0.19 \\
\hline
\end{tabular}

${ }^{1}$ Data are least squares means from all 8 cows used in the two Latin squares.

${ }^{2}$ WDDGS-Peas $=$ wheat dried distillers grains with solubles plus peas; WDDS-CM $=$ wheat dried distillers grains with solubles plus canola meal. ${ }^{3}$ Source $=$ effect of source of dietary supplement (WDDS-Peas vs. WDDGS-CM); Extrusion = effect of extrusion processing (extruded vs. nonextruded); and $\mathrm{S} \times \mathrm{E}=$ interaction.

${ }^{4}$ Calculated as $(0.434 \times \mathrm{kg}$ of milk $)+(16.216 \times \mathrm{kg}$ of milk fat $)$.

could be partly attributed to loss of oil due to leaching during extrusion processing (Imran et al., 2014). By design, dietary $\mathrm{CP}$ contents of experimental TMR were similar (Table 2). We noted only small differences in ADF, NDF, and starch contents of experimental TMR that contained the WDDGS-CM and WDGGS-peas supplements, which are reflective of the differences in chemical compositions of the respective supplements. There were no differences in the chemical compositions of experimental TMR due to extrusion processing.

\section{DMI, Milk Yield, and Milk Components}

Dry matter intake was not affected $(P>0.05)$ by dietary treatment (Table 3). Actual milk yield (42.9 vs. $40.8 \mathrm{~kg} / \mathrm{d}$; $\mathrm{SEM}=2.01$ ) and $3.5 \% \mathrm{FCM}$ (42.9 vs. $41.3 \mathrm{~kg} / \mathrm{d}$; SEM $=2.01)$ yield were greater $(P=0.03)$ in cows fed coextruded diets compared with those fed nonextruded diets. Actual milk yield tended $(P=0.06)$ to be greater ( 43.5 vs. $40.2 \mathrm{~kg} / \mathrm{d}$; $\mathrm{SEM}=2.29$ ) in cows fed diets containing WDDGS-peas compared with those fed diets containing WDDGS-CM; however, FCM yield was similar in cows fed diets containing WDDGS$\mathrm{CM}$ and WDDGS-peas. Milk fat content was greater $(P=0.04)$ in cows fed nonextruded diets compared with those fed coextruded diets (3.58 vs. 3.53\%; SEM $=0.24)$, but milk fat yield $(1.50$ vs. $1.44 \mathrm{~kg} / \mathrm{d} ; \mathrm{SEM}=$ $0.052)$ was greater $(P=0.03)$ in cows fed coextruded diets compared with those fed nonextruded diets. Milk protein content was not affected $(P>0.05)$ by diet, but milk protein yield was greater $(P<0.05)$ in cows fed diets containing WDDGS-peas compared with those fed diets containing WDDGS-CM diets (1.38 vs. 1.29 $\mathrm{kg} / \mathrm{d} ; \mathrm{SEM}=0.062)$. Milk lactose content $(P=0.01$;
4.55 vs. $4.48 \%$; SEM $=0.031)$ and milk lactose yield $(P$ $=0.01 ; 1.95$ vs. $1.83 \mathrm{~kg} / \mathrm{d} ; \mathrm{SEM}=0.09)$ were greater in cows fed coextruded diets compared with those fed nonextruded diets. Cows fed nonextruded diets had greater $(P=0.01)$ MUN concentrations compared with those fed coextruded diets (15.7 vs. $14.9 \mathrm{mg} / \mathrm{dL} ; \mathrm{SEM}$ $=0.72)$.

\section{Ruminal Fermentation Characteristics and Plasma Metabolites}

Ruminal $\mathrm{pH}$ was greater in cows fed coextruded WDDGS-peas compared with those fed coextruded WDDGS-CM, but ruminal $\mathrm{pH}$ was lower in cows fed nonextruded WDDGS-peas compared with those fed nonextruded WDDGS-CM (interaction, $P=0.04$; Table 4). Ruminal $\mathrm{NH}_{3}-\mathrm{N}$ concentration tended $(P=0.06)$ to be greater in cows fed diets containing WDDGS-CM compared with those fed diets containing WDDGSpeas (11.8 vs. $10.5 \mathrm{mg} / \mathrm{dL} ; \mathrm{SEM}=0.56)$. For cows fed coextruded diets, ruminal acetate concentration was greater in cows fed WDDGS-CM compared with those fed WDDGS-peas; however, for cows fed nonextruded diets, ruminal acetate concentration was lower for cows fed WDDGS-CM compared with those fed WDDGSpeas (interaction, $P=0.02$ ). Ruminal propionate concentration was greater in cows fed coextruded diets containing WDDGS-CM compared with those fed diets containing WDDGS-peas, but we found no difference in ruminal propionate concentration for cows fed nonextruded diets (tendency for an interaction, $P=0.08$ ). The acetate-to-propionate ratio was not affected by dietary treatment $(P>0.05)$. Ruminal concentrations of butyrate (interaction, $P<0.01$ ) and isovalerate (in- 
Table 4. Ruminal fermentation characteristics, plasma urea-N, and plasma glucose in dairy cows fed the 4 experimental diets ${ }^{1}$

\begin{tabular}{|c|c|c|c|c|c|c|c|c|}
\hline \multirow[b]{2}{*}{ Item } & \multicolumn{2}{|c|}{ Coextruded $^{2}$} & \multicolumn{2}{|c|}{ Nonextruded $^{2}$} & \multirow[b]{2}{*}{ SEM } & \multicolumn{3}{|c|}{$P$-value ${ }^{3}$} \\
\hline & WDDGS-Peas & WDDGS-CM & WDDGS-Peas & WDDGS-CM & & $\begin{array}{l}\text { Source } \\
(\mathrm{S})\end{array}$ & $\begin{array}{l}\text { Extrusion } \\
\quad(\mathrm{E})\end{array}$ & $\mathrm{S} \times \mathrm{E}$ \\
\hline $\begin{array}{l}\text { Ruminal } \mathrm{NH}_{3}-\mathrm{N}, \mathrm{mg} / \mathrm{dL} \\
\mathrm{SCFA}^{4} \text { concentration, } \mathrm{m} M\end{array}$ & 10.08 & 12.32 & 10.85 & 11.28 & 0.61 & 0.06 & 0.84 & 0.19 \\
\hline Acetate & $61.3^{\mathrm{ab}}$ & $64.9^{\mathrm{a}}$ & $60.8^{\mathrm{ab}}$ & $58.1^{\mathrm{b}}$ & 2.0 & 0.72 & $<0.01$ & 0.02 \\
\hline Isobutyrate & 0.78 & 0.87 & 0.80 & 0.83 & 0.02 & $<0.01$ & 0.79 & 0.11 \\
\hline Valerate & 1.42 & 1.93 & 1.64 & 1.57 & 0.14 & 0.14 & 0.65 & 0.07 \\
\hline Isovalerate & $1.12^{\mathrm{b}}$ & $1.27^{\mathrm{a}}$ & $1.21^{\mathrm{ab}}$ & $1.19^{\mathrm{ab}}$ & 0.05 & 0.03 & 0.78 & $<0.01$ \\
\hline Total SCFA & 96 & 106 & 97 & 91 & 9.6 & 0.64 & 0.18 & 0.15 \\
\hline Acetate:propionate ratio & 3.10 & 2.71 & 3.23 & 3.23 & 0.26 & 0.30 & 0.10 & 0.28 \\
\hline Plasma urea-N, mg/dL & 14.0 & 14.8 & 15.4 & 14.8 & 0.7 & 0.93 & 0.10 & 0.11 \\
\hline Plasma glucose, $\mathrm{mg} / \mathrm{dL}$ & $52.2^{\mathrm{d}}$ & $59.2^{\mathrm{a}}$ & $53.1^{\mathrm{c}}$ & $57.7^{\mathrm{b}}$ & 1.4 & $<0.01$ & 0.02 & $<0.01$ \\
\hline
\end{tabular}

${ }^{\mathrm{a}-\mathrm{d}}$ Means within a row with different superscripts differ $(P<0.05)$.

${ }^{1}$ Data are least squares means from 4 (ruminal fermentation characteristics) or 8 (plasma metabolites) cows used in the 2 Latin squares.

${ }^{2}$ WDDGS-Peas $=$ wheat dried distillers grains with solubles plus peas; WDDS-CM $=$ wheat dried distillers grains with solubles plus canola meal. ${ }^{4}$ Source $=$ effect of source of dietary supplement (WDDS-Peas vs. WDDGS-CM); Extrusion = effect of extrusion processing (extruded vs. nonextruded); and $\mathrm{S} \times \mathrm{E}=$ interaction.

${ }^{5}$ Short-chain fatty acids.

teraction, $P<0.01)$ were similar among cows fed nonextruded diets; however, cows fed coextruded WDDGSCM had greater ruminal concentrations of butyrate and isovalerate than those fed coextruded WDDGS-peas. Ruminal valerate concentration tended to be greater in cows fed coextruded WDDGS-CM compared with those fed coextruded WDDGS-peas; however, ruminal concentrations of valerate in cows fed nonextruded diets were similar (tendency for an interaction, $P=0.07$ ). Ruminal isobutyrate concentration was greater $(P<$ 0.01) in cows fed WDDGS-CM diets compared with those fed WDDGS-peas diets (0.85 vs. $0.79 \mathrm{~m} M$; SEM $=0.017)$. Total ruminal SCFA concentrations were not affected by diet $(P>0.05)$.

Plasma urea-N concentration tended $(P=0.10)$ to be lower in cows fed coextruded diets compared with those fed nonextruded diets (Table 4). Plasma glucose concentration was greater in cows fed diets containing WDDGS-CM compared with those fed diets containing WDDGS-peas, but the difference in plasma glucose concentration between WDDGS-CM and WDDGS-peas was greater in cows fed coextruded diets compared with those fed nonextruded diets (interaction, $P<0.01$ ).

\section{Ruminal and Total-Tract Nutrient Digestion and Omasal Nutrient Flows}

For the ruminally cannulated cows $(\mathrm{n}=4)$ that were used in the metabolism study, intake and omasal flow of DM were not affected by $\operatorname{diet}(P>0.05$; Table 5$)$; however, percent of DM that was apparently digested in the rumen was greater $(P=0.02)$ in cows fed coextruded diets compared with those fed nonextruded diets (34.6 vs. $30.3 \%$ of DMI). Intake of OM was greater $(P=0.011)$ in cows fed coextruded diets compared with those fed nonextruded diets (27.4 vs. $24.3 \mathrm{~kg} / \mathrm{d}$; $\mathrm{SEM}=0.95)$, but $\mathrm{OM}$ flow and $\mathrm{OM}$ apparently digested in the rumen did not differ among diets $(P>$ $0.05)$. The amount of OM truly digested in the rumen did not differ among diets; however, OM truly digested in the rumen expressed as a percent of OM intake did not differ between cows fed diets containing WDDGSpeas but tended to be greater in cows fed coextruded WDDGS-CM compared with those fed nonextruded WDDGS-CM (tendency for an interaction, $P=0.06$ ). Intakes of NDF and ADF and their apparent ruminal digestion were not different among diets $(P>0.05)$; however, omasal flows of $\operatorname{ADF}(P=0.03 ; 2.13$ vs. 1.89 $\mathrm{kg} / \mathrm{d}: \mathrm{SEM}=0.08)$ and NDF $(P=0.03 ; 4.25$ vs. 3.96 $\mathrm{kg} / \mathrm{d} ; \mathrm{SEM}=0.18$ ) were greater in cows fed diets containing WDDGS-CM compared with those fed diets containing WDDGS-peas. Starch intake was greater $(P$ $=0.03)$ in cows fed coextruded diets compared with those fed nonextruded diets (6.46 vs. $5.91 \mathrm{~kg} / \mathrm{d} ; \mathrm{SEM}$ $=0.22)$, and was also greater $(P=0.04)$ in cows fed diets containing WDDGS-peas compared with those fed diets containing WDDGS-CM (6.43 vs. $5.94 \mathrm{~kg} / \mathrm{d}$; $\mathrm{SEM}=0.22$. . Omasal flow of starch was similar in cows fed nonextruded diets; however, cows fed the diet containing coextruded WDDGS-peas tended to have a greater omasal flow of starch compared with those fed the diet containing coextruded WDDGS-CM (tendency 
Table 5. Intake, omasal flow, and ruminal and total-tract digestion of nutrients in dairy cows fed the 4 experimental diets $^{1}$

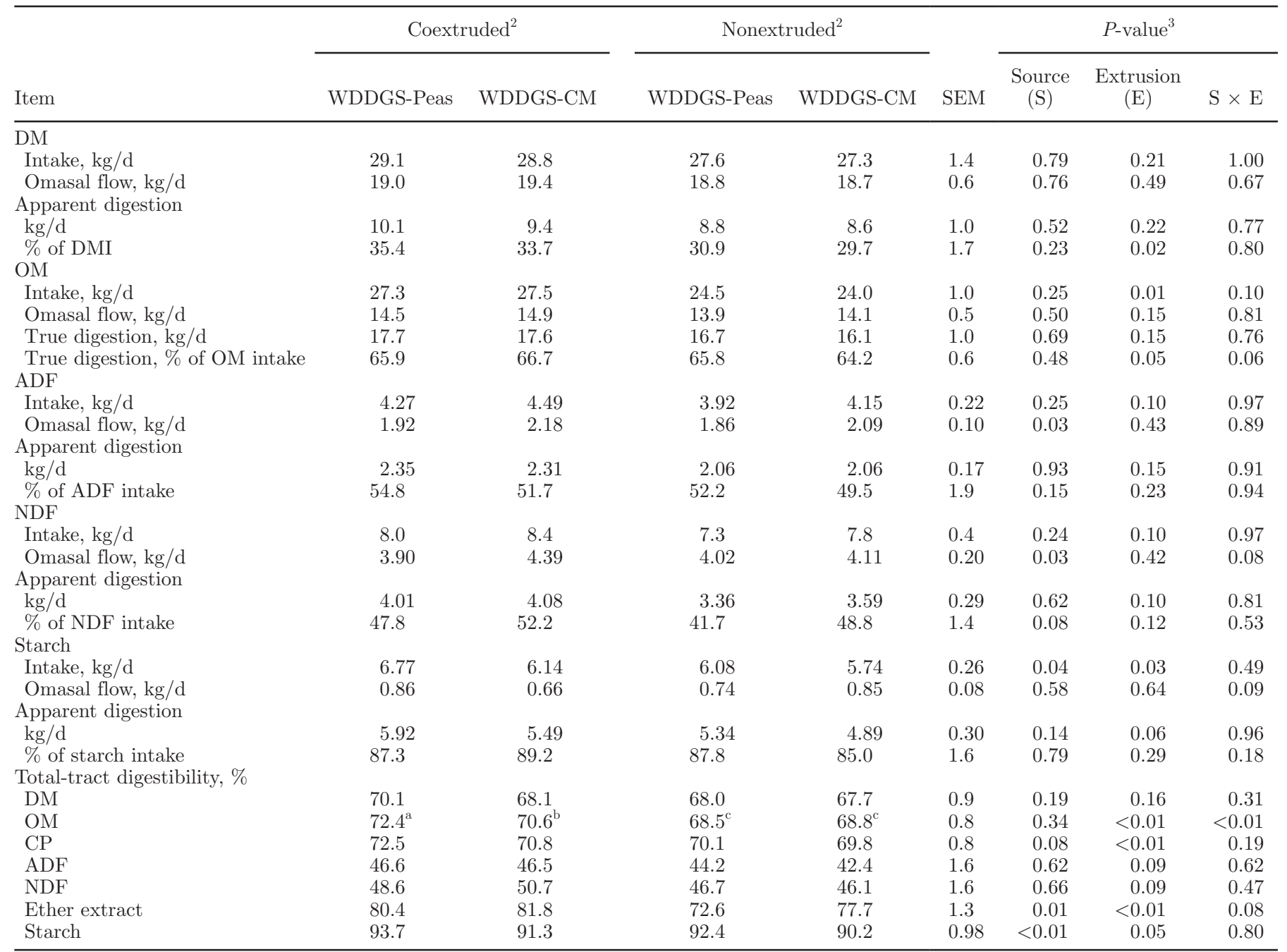

${ }^{\mathrm{a}-\mathrm{c}}$ Means within a row with different superscripts differ $(P<0.05)$.

${ }^{1}$ Data are LSM from 4 ruminally cannulated cows used in 1 Latin square. Data on nutrient intakes were calculated based on DMI that were measured during omasal sampling (i.e., d 20 to 23). Data on total-tract nutrient digestion were calculated based on DMI that were measured during the 4-d total fecal and urine collections (i.e., d 24 to 28).

${ }^{2}$ WDDGS-Peas $=$ wheat dried distillers grains with solubles plus peas; WDDS-CM $=$ wheat dried distillers grains with solubles plus canola meal. ${ }^{3}$ Source $=$ effect of source of dietary supplement (WDDS-Peas vs. WDDGS-CM); Extrusion = effect of extrusion processing (extruded vs. nonextruded); and $\mathrm{S} \times \mathrm{E}=$ interaction.

for interaction, $P=0.09)$. The amount of starch apparently digested in the rumen tended to be greater $(P=$ $0.06)$ in cows fed coextruded diets compared with those fed nonextruded diets $(5.70$ vs. $5.11 \mathrm{~kg} / \mathrm{d} ; \mathrm{SEM}=0.24)$

Apparent total-tract digestibility of DM was not affected $(P>0.05)$ by dietary treatment (Table 5). Apparent total-tract $\mathrm{OM}$ digestibility was similar in cows fed nonextruded diets, but total-tract OM digestibility was greater in cows fed diets containing coextruded WDDGS-peas compared with those fed diets containing coextruded WDDGS-CM (interaction, $P<0.01$ ). Apparent total-tract $\mathrm{CP}$ digestibility was greater $(P<$ 0.01 ) in cows fed coextruded diets compared with those fed nonextruded diets (71.6 vs. 69.9\%), and tended to be greater $(P=0.08)$ in cows fed diets containing WDDGS-peas compared with those fed diets containing WDDGS-CM (71.3 vs. $70.3 \%$. Apparent total-tract digestibilities of ADF (46.5 vs. $43.3 \%$ ) and NDF (49.6 vs. $46.4 \%)$ tended to be greater $(P=0.09)$ in cows fed coextruded diets compared with those fed nonextruded diets. Apparent total-tract EE digestibility was greater in cows fed diets containing WDDGS-CM compared with those fed WDDGS-peas, but the difference was greater in cows fed nonextruded compared with those fed coextruded diets (tendency for an interaction, $P$ $=0.08)$. Apparent total-tract starch digestibility was 
greater $(P<0.01)$ in cows fed containing WDDGS-peas compared with those fed diets containing WDDGS-CM (93.1 vs. $90.7 \%)$, and it was also greater $(P=0.05)$ in cows fed coextruded diets compared with those fed nonextruded diets (92.5 vs. $91.3 \%$ ).

\section{Nitrogen Balance and Intake, Digestibility, and Omasal Flows of Nitrogen Fractions and Microbial Protein Synthesis}

Dietary treatment had no effect $(P>0.05)$ on $\mathrm{N}$ intake, and excretion of total $\mathrm{N}$ and fecal $\mathrm{N}$ (Table 6); however, fecal $\mathrm{N}$ when expressed as a proportion of $\mathrm{N}$ intake was greater $(P=0.01)$ in cows fed nonextruded diets compared with those fed coextruded diets (30.1 vs. $28.4 \%)$, and it tended to be greater $(P=0.08)$ in cows fed diets containing WDDGS-CM compared with those fed WDDGS-peas (29.7 vs. 28.7\%). Urinary N excretion was not affected by dietary treatment $(P$ $>0.05$ ); however, when expressed as a proportion of urinary $\mathrm{N}$, urea-N excretion was greater in cows fed WDDGS-peas compared with those fed WDDGS-CM with nonextruded diets, but no difference was noted between cows fed coextruded diets (interaction, $P=$
$0.01)$. Milk $\mathrm{N}, \mathrm{N}$ retention, and productive $\mathrm{N}$ were not affected $(P>0.05)$ by dietary treatment.

Nitrogen apparently or truly digested in the rumen, RDP and RUP supply, and omasal flows of $\mathrm{N}, \mathrm{NH}_{3}-\mathrm{N}$, $\mathrm{NAN}$, non- $\mathrm{NH}_{3}$ nonbacterial $\mathrm{N}, \mathrm{FAB} \mathrm{NAN}$, and $\mathrm{PAB}$ NAN, and microbial efficiency did not differ among diets $(P>0.05$; Table 7$)$. Total bacterial NAN flow at the omasal canal was greater $(P=0.05)$ in cows fed diets containing WDDGS-CM compared with those fed diets containing WDDGS-peas (548 vs. $519 \mathrm{~g} / \mathrm{d}$; SEM $=10)$, and tended to be greater $(P=0.10)$ in cows fed coextruded diets compared with those fed nonextruded diets (541 vs. $526 \mathrm{~g} / \mathrm{d}$; SEM = 10); however, when expressed as a proportion of total NAN, total bacterial NAN did not differ among diets $(P>0.05)$.

\section{DISCUSSION}

No interactions between source of dietary supplement and extrusion processing were observed for production parameters in the present study, so main effects will be discussed. We are not aware of similar studies that have reported the effects of the co-extrusion of WDDGS-CM or WDDGS-peas mixtures on production parameters in

Table 6. Nitrogen intake, fecal and urinary $\mathrm{N}$ excretion, milk $\mathrm{N}$, and $\mathrm{N}$ efficiency in dairy cows fed the 4 experimental diets $^{1}$

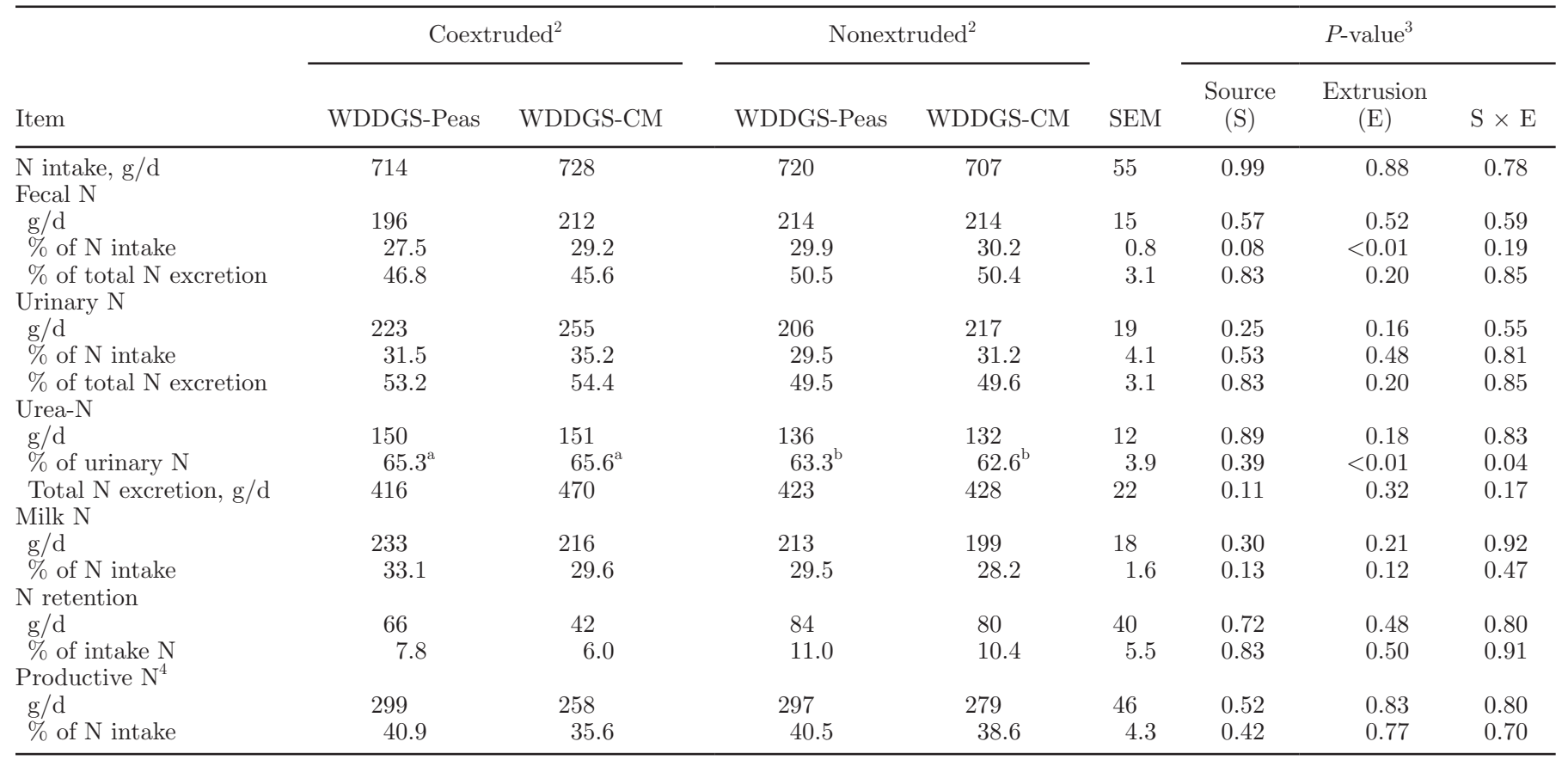

${ }_{\mathrm{a}, \mathrm{b}}$ Means within a row with different superscripts differ $(P<0.05)$.

${ }^{1}$ Data are LSM from 4 ruminally cannulated cows used in 1 Latin square. Data on N intakes were calculated based on DMI that were measured during the 4-d total fecal and urine collections (i.e., d 24 to 28 ).

${ }^{2}$ WDDGS-Peas $=$ wheat dried distillers grains with solubles plus peas; WDDS-CM $=$ wheat dried distillers grains with solubles plus canola meal. ${ }^{3}$ Source $=$ effect of source of dietary supplement (WDDS-Peas vs. WDDGS-CM); Extrusion = effect of extrusion processing (extruded vs. nonextruded); and $\mathrm{S} \times \mathrm{E}=$ interaction.

${ }^{4}$ Productive $\mathrm{N}$ was calculated as the sum of milk $\mathrm{N}$ and $\mathrm{N}$ retention. 
dairy cows, so direct comparisons of our observations with other published studies are not possible. Intake of DM was not affected by extrusion, which is in agreement with other studies that have reported a lack of effect on DMI due to the extrusion of various feedstuffs such as peas, canola seed, and flaxseed (Petit et al., 1997; Gonthier et al., 2005; Petit, 2010; Neveu et al., 2013). According to Allen (2000), high dietary NDF can limit DMI in high-producing cows due to rumen fill. Based on practical models that were developed to predict the adequacy of dietary fiber, Zebeli et al. (2008) indicated that dietary NDF content $>32 \%$ can limit DMI of highproducing dairy cows. All experimental diets that were used in the present study contained $\leq 29 \% \mathrm{NDF}$, so NDF content was not expected to limit DMI. Walhain et al. (1992) reported that extrusion could potentially decrease the fiber content in feed ingredients (peas) by increasing the proportion of soluble dietary fiber; how-

Table 7. Intakes, ruminal digestion, and omasal flows of nitrogen fractions in dairy cows fed the 4 experimental diets ${ }^{1}$

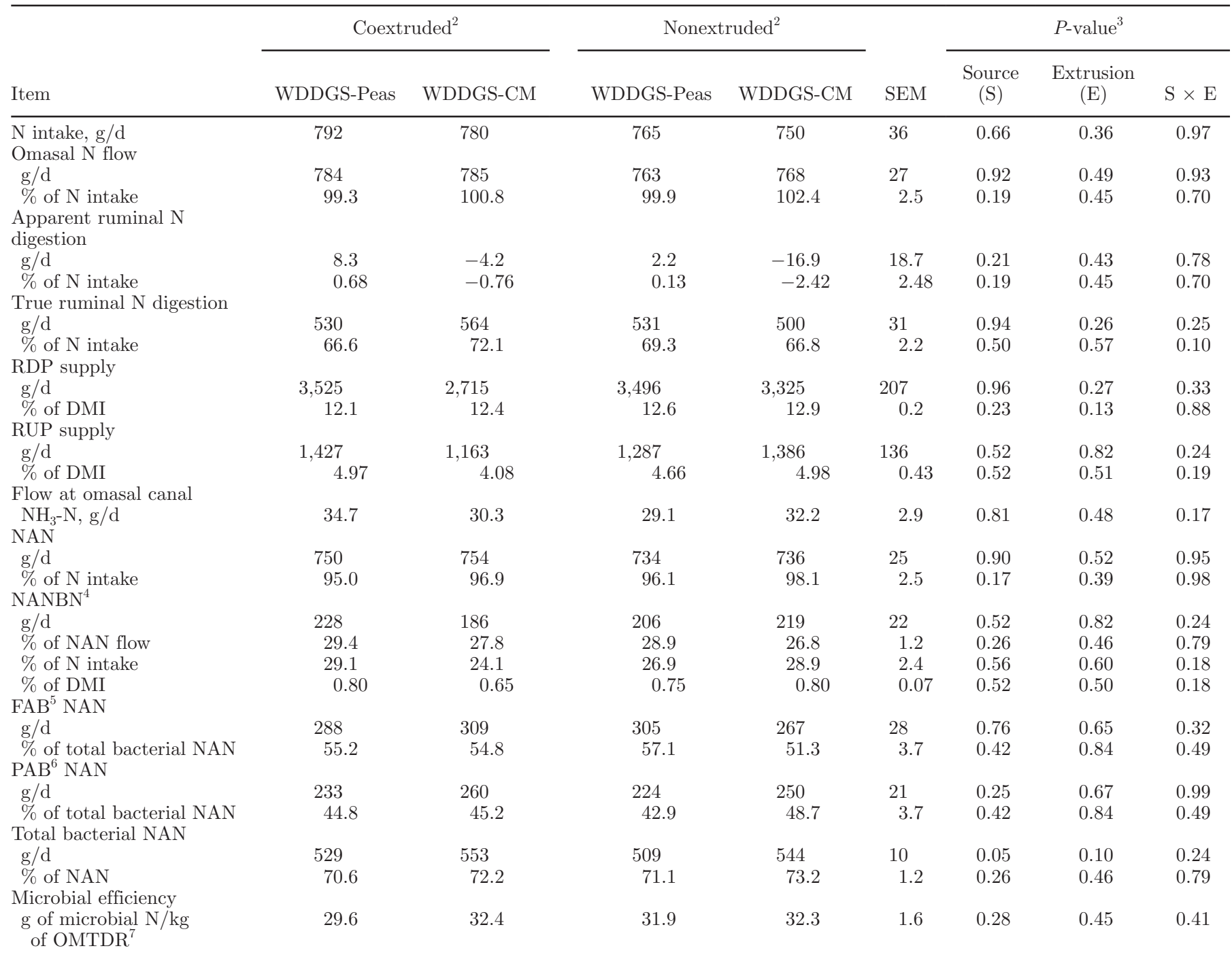

${ }^{1}$ Data are LSM from 4 ruminally cannulated cows used in 1 Latin square. Data on N intakes, ruminal digestion, and omasal flow of $\mathrm{N}$ fractions were calculated based on DMI that were measured during omasal sampling (i.e., d 20 to 23).

${ }^{2}$ WDDGS-Peas $=$ wheat dried distillers grains with solubles plus peas; WDDS-CM $=$ wheat dried distillers grains with solubles plus canola meal. ${ }^{3}$ Source $=$ effect of source of dietary supplement (WDDS-Peas vs. WDDGS-CM); Extrusion $=$ effect of extrusion processing (extruded vs. nonextruded); and $\mathrm{S} \times \mathrm{E}=$ interaction.

${ }^{4} \mathrm{NANBN}=$ non- $\mathrm{NH}_{3}$ nonbacterial $\mathrm{N}$.

${ }^{7} \mathrm{FAB}=$ fluid-associated bacteria.

${ }^{8} \mathrm{PAB}=$ particle-associated bacteria.

${ }^{9} \mathrm{OMTDR}=$ organic matter truly digested in the rumen. 
ever, although we did not measure dietary soluble fiber in the present study, extrusion did not alter dietary NDF content which could further explain why DMI were not influenced by extrusion.

Most of the major effects on production parameters that we observed were attributed to extrusion rather than source of dietary supplement. Extrusion increased milk yield by $2.1 \mathrm{~kg} / \mathrm{d}$, and this positive response in milk yield is in agreement with Masoero et al. (2006), who reported that cows fed extruded peas produced more milk when compared with those fed raw peas; however, Petit et al. (1997) failed to detect any responses in milk yield in cows fed extruded or nonextruded peas. In general, milk yield is positively correlated with DMI (NRC, 2001); however, in the present study, greater milk yields with coextruded diets were not associated with greater DMI, which would suggest that alternative mechanisms accounted for the greater milk yields. We observed that ruminal or total-tract digestibilities (in absolute amounts or as a proportion of intake) of most dietary constituents (fiber, starch, EE, and N) and microbial NAN flow at the omasal canal were greater or tended to be greater for cows fed coextruded diets compared with those fed nonextruded diets, thus suggesting a greater nutrient supply that would go toward supporting the higher levels of milk production observed. Cows fed diets containing WDDGS-peas tended to produce more milk compared with those fed WDDGS-CM. Although this response was only a tendency statistically, it was numerically rather large $(3.3 \mathrm{~kg} / \mathrm{d})$, suggesting that it was biologically significant; the lack of statistical significance could partly reflect the low number of animals $(\mathrm{n}=8)$ used. A greater nutrient supply arising from greater total-tract digestibilities of starch and CP could partly be responsible for the greater milk yields that we observed with WDDGS-peas diets. Comparative studies with dairy cows involving peas and CM are scarce. In support of our findings, Corbett et al. (1995) replaced a standard concentrate that contained CM and soybean meal as the major protein sources with peas in diets for early-lactation cows and observed that FCM yield was greater $(+1.6 \mathrm{~kg} / \mathrm{d})$ with the peas-based diet.

Milk fat content was decreased in cows fed coextruded diets compared with those fed nonextruded diets. The effects of extrusion on milk fat content have been equivocal, with some studies reporting no change (Petit et al., 1997; Neveu et al., 2013), an increase (Jones et al., 2001), or a decrease (Moallem, 2009; Neves et al., 2009) in milk fat content when extruded diets were fed to dairy cows. Heat processing methods such as extrusion have been suggested to protect PUFA that are contained in oilseeds and grains from ruminal biohydrogenation (Chouinard et al., 1997). However, because extrusion also ruptures the oilseeds or grains, leading to the release of oil and its exposure to ruminal microbial activity, extrusion does not completely protect dietary PUFA from ruminal biohydrogenation (Neves et al., 2009). Thus, feeding extruded oilseeds or grains can result in the formation of biohydrogenation intermediates such as C18:1 trans-10 and CLA trans-10,cis-12, which are potent inhibitors of de novo milk fat synthesis in the mammary gland (Baumgard et al., 2000; Bauman and Griinari, 2001). We did not measure milk fatty acid composition in the present study, but other studies (Mustafa et al., 2003; Gonthier et al., 2005) have reported greater milk fat concentrations of C18:1 trans-10 and CLA trans-10,cis-12 CLA in cows fed extruded diets. Although milk fat content was decreased by feeding extruded diets, milk fat yield was actually greater in cows fed extruded diets compared with those nonextruded diets, and this response can be attributed to the greater milk yields with extruded diets.

We did not observe any effects of extrusion on milk protein content or yield; however, other studies have observed positive effects of extrusion on milk protein content (Petit et al. 1997) and yield (Jones et al. 2001; Masoero et al. 2006). Increased milk protein content with dietary manipulation would suggest an increased availability of AA for milk protein synthesis. Although extrusion increased total-tract $\mathrm{CP}$ digestibility and tended to increase postruminal flow of microbial NAN in the present study, this did not result in an increase in milk protein content, which would suggest that the greater CP digestibility and microbial NAN flow might not necessarily have resulted in a greater AA supply to the mammary gland. Plasma urea-N and MUN are used as indicators of $\mathrm{N}$ efficiency, with lower concentrations indicating improved efficiency (Colmenero and Broderick, 2006). In the present study, cows fed extruded diets had lower MUN concentrations and tended to have lower plasma urea- $\mathrm{N}$ concentrations compared with those fed nonextruded diets, in agreement with other studies (Jones et al., 2001). Milk urea-N is derived from plasma urea- $\mathrm{N}$, which, in turn, is derived from hepatic ureagenesis with ruminally derived $\mathrm{NH}_{3^{-}}$ $\mathrm{N}$ being the main source of $\mathrm{N}$. In the present study, however, ruminal $\mathrm{NH}_{3}-\mathrm{N}$ concentrations were not influenced by extrusion, which suggests that differences in plasma urea-N and MUN due to extrusion cannot be attributed to changes in portal uptake of ruminal $\mathrm{NH}_{3}$ $\mathrm{N}$, as this is a concentration-dependent process. Cows fed coextruded diets exhibited greater milk lactose content and yields compared with those fed nonextruded diets, with the greater lactose yield being attributable to both the greater milk yield and lactose content with coextruded diets. Neves et al. (2009) observed an increase in lactose yield with extruded compared with raw canola seeds, a response that was attributed to a 
numerical, but not significant, increase in milk yield as lactose content was similar. Positive responses in milk lactose content can be partly attributed to a greater supply of gluconeogenic precursors such as propionate and AA (Broderick, 2003; Jenkins and McGuire, 2006; Sterk et al., 2011). In the present study, ruminal propionate concentrations, total-tract $\mathrm{CP}$ digestibility, and omasal flow of microbial NAN were greater in cows fed coextruded diets compared with those fed nonextruded diets, so we can surmise that feeding coextruded diets could have increased the supply of gluconeogenic precursors; however, although it was positive, the response in plasma glucose concentrations to feeding extruded diets was rather small.

Our results show that most of the major dietary effects on ruminal and total-tract nutrient digestion observed were due to extrusion rather than the source of dietary supplement (i.e., WDDGS-peas vs. WDDGS-CM). For cows that were fed coextruded diets, ruminal DM and OM digestibilities (when expressed as a proportion of DM or OM intake) were greater than in cows fed nonextruded diets. Our observations are in agreement with those reported by Gonthier et al. (2004); however, perusal of the literature indicates that the effects of extrusion on ruminal digestibility are rather inconsistent, with some studies (Pena et al., 1986; Chouinard et al., 1997) reporting reduced ruminal degradability whereas others (Stern et al., 1985; Deacon et al., 1988) reported minor effects. It is noteworthy that most of these studies were conducted with oilseeds (e.g., soybeans and flaxseed) that contained significantly greater amounts of lipid compared with the WDDGS-peas and WDDGS-CM mixtures used in the present study. It has been suggested that the high oil content in oilseeds could potentially limit the disruption of cell structures because both shearing forces and heat elevation inside the extruder might be reduced (Gonthier et al., 2004). Because of the lower lipid content in the WDDGS-peas and WDDGS-CM mixtures, this could have caused a greater disruption of cell structures, which, as a result, would increase ruminal degradability of DM and OM. Consistent with other studies (Gonthier et al., 2004), ruminal digestion of NDF (expressed as absolute amounts or as a proportion of NDF intake) was also increased by extrusion. Total-tract digestibilities of OM, fiber, starch, and EE were greater in cows fed coextruded diets compared with those fed nonextruded diets, suggesting that postruminal digestion failed to compensate for the lower ruminal digestion of nutrients with nonextruded diets. Other studies (Scott et al., 1991; Petit et al., 1997; Gonthier et al., 2004) conducted with high-oil diets containing oilseeds failed to detect differences in total-tract nutrient digestibility. Only minor effects on ruminal or total-tract nutrient digestion were observed due to the source of dietary supplement (i.e., WDDGSpeas vs. WDDGS-CM). Apparent ruminal digestion of NDF tended to be greater in cows fed WDDGS-CM compared with those fed WDDGS-peas. Wheat dried distillers grains with solubles contains readily fermentable fiber (Schingoethe et al., 2009; Sun and Oba, 2014), so the differences in ruminal NDF digestion between WDDGS-peas and WDDGS-CM mixtures likely reflect differences in fiber digestion between CM and peas. For cows fed coextruded diets, the amount of starch that was ruminally digested tended to be greater and totaltract starch digestibility was greater when compared with cows fed nonextruded diets. It is well known that exposure to heat treatment during extrusion processing of starch-containing feeds will cause starch gelatinization (Svihus et al., 2005), which will increase ruminal and postruminal starch digestion. Our results are consistent with previous studies that have reported greater starch digestion with extrusion processing (Chapoutot and Sauvant, 1997; Petit et al. 1997).

Because extrusion can reduce the ruminal solubility and degradability of dietary protein (NRC, 2001), we had anticipated that feeding coextruded diets would generally improve $\mathrm{N}$ utilization in dairy cows compared with feeding nonextruded diets. Also, because of differences in the chemical compositions and ruminal degradabilities of WDDGS, CM, and peas, we had anticipated that feeding judicious mixtures of WDDGS-peas and WDDGS-CM would also influence N utilization. Our results indicate that extrusion processing and source of dietary supplement had only minor effects on $\mathrm{N}$ utilization. Extrusion processing had no effects on ruminal CP degradability, contrary to previous studies that have reported decreased (Gonthier et al., 2004) or increased (Meyer et al., 2001) ruminal CP degradability with extrusion processing. In general, heat treatment of proteinaceous feed ingredients such as oilseeds shifts the site of CP digestion from the reticulorumen to postruminal sites (Aldrich et al., 1995; Wang et al., 1999); however, it appears that the application of heat through extrusion processing is less effective in protecting dietary protein from ruminal degradation when compared with other methods of heat treatment, such as micronization (Gonthier et al., 2004). By-product feeds, such as CM and WDDGS, can vary greatly in chemical composition and ruminal CP degradability characteristics due to grain source, processing conditions, such as extent of drying and drying temperatures, and plant of origin (Kleinschmit et al., 2007; Maxin et al., 2013b); thus, variations may exist in ruminal $\mathrm{CP}$ degradability of a single feed ingredient (e.g., CM) obtained from different sources or even from batch to batch within the same plant (Nuez-Ortín and Yu, 2010). Such differences could influence the effectiveness of extrusion 
processing on different protein sources, thus potentially diminishing the anticipated changes in ruminal $\mathrm{N}$ utilization. Apparent total-tract digestibility of $\mathrm{CP}$ was increased when feeding coextruded diets compared with nonextruded diets, which is in agreement with other studies (Petit et al., 1997). Other studies (Benchaar et al., 1994; Solanas et al., 2008) have observed increased intestinal CP digestibility with extrusion processing.

The omasal flow of bacterial NAN tended to be greater in cows fed coextruded diets compared with those fed nonextruded diets. This response could be partly attributed to a greater starch intake and a numerically greater $(0.6 \mathrm{~kg} / \mathrm{d})$ extent of ruminal starch digestion with coextruded diets, which could have supplied more fermentable energy for microbial growth; however, it should be noted that the difference in omasal NAN flow was rather small (approximately $14 \mathrm{~g} / \mathrm{d}$ ). Others (Orias et al., 2002; Gonthier et al., 2004) reported that heat treatment had no effects on duodenal flow of microbial NAN. Dietary RDP supply has a major influence in microbial growth in the rumen as it supplies $\mathrm{N}$ precursors (i.e., $\mathrm{NH}_{3}-\mathrm{N}, \mathrm{AA}$, and peptides) that are required for protein synthesis (NRC, 2001). The NRC (2001) recommends that dietary RDP levels should be 9.5 to $10.5 \%$ of DM, and supplying RDP below these levels can depress microbial protein synthesis due to a deficiency in ruminal $\mathrm{N}$ precursors (Broderick et al., 2007). In the present study, dietary RDP levels ranged from 12.1 to $12.9 \%$ of DM, so it is unlikely that microbial growth was limited by ruminal N supply. Satter and Slyter (1974) suggested that the minimum ruminal $\mathrm{NH}_{3}-\mathrm{N}$ concentration that is required for optimum microbial protein synthesis is $5 \mathrm{mg} / \mathrm{dL}$. It is noteworthy that, in the present study, mean ruminal $\mathrm{NH}_{3}-\mathrm{N}$ concentrations on all diets were $>10 \mathrm{mg} / \mathrm{dL}$ so it is unlikely that ruminal $\mathrm{NH}_{3}-\mathrm{N}$ was deficient.

Ruminal fermentation characteristics were altered by both extrusion processing and the source of dietary supplement. Feeding coextruded diets depressed ruminal $\mathrm{pH}$ when compared with feeding nonextruded diets, supporting previous findings (Focant et al., 1990). Extrusion processing of starchy feeds has been reported to consistently increase ruminal starch degradation due to starch gelatinization (see review by Svihus et al., 2005), which would increase ruminal SCFA production and, subsequently, depress ruminal $\mathrm{pH}$. In the current study, the amount of starch that was digested in the rumen was greater with coextruded compared with nonextruded diets. In addition, although not statistically significant, the numerical increase in the ruminal concentration of total SCFA we observed in cows fed coextruded diets in the present study is in agreement with the greater ruminal starch digestion and depression in ruminal $\mathrm{pH}$. We observed that ruminal $\mathrm{NH}_{3} \mathrm{~N}$ concentration tended to be greater in cows fed diets containing WDDGS-CM compared with those fed diets containing WDDGS-peas, although these diets were isonitrogenous. The reasons for this response are unclear; although peas contain more RDP than CM (Boila and Ingalls, 1994; NRC, 2001) their CP content is lower than that of CM, and their contribution to dietary RDP supply would be smaller than that of $\mathrm{CM}$ when included in the diet at similar levels. Also, the greater starch intake $(0.49 \mathrm{~kg} / \mathrm{d})$ and numerically greater amount of starch that was digested in the rumen $(0.44 \mathrm{~kg} / \mathrm{d})$ in cows fed WDDGS-peas compared with those fed WDDGS-CM could have provided more ruminally fermentable energy to support microbial sequestration of ruminal $\mathrm{NH}_{3}-\mathrm{N}$, thus resulting in a lower ruminal $\mathrm{NH}_{3}-\mathrm{N}$ concentrations with WDDGS-peas.

\section{CONCLUSIONS}

Results from our study indicate that most of the effects we observed on production performance, ruminal fermentation characteristics, omasal nutrient flows, and total-tract nutrient digestibilities were attributed to extrusion processing rather than the WDDGS-peas or WDDGS-CM supplement combinations. Although they were no dietary effects on feed intake, extrusion processing increased milk production. The increase in milk production could be attributed to a greater nutrient supply in cows fed coextruded diets due to greater ruminal and total-tract digestibilities for most dietary constituents and a tendency for a greater microbial NAN supply when compared with cows fed nonextruded diets. However, the results that we obtained on production variables should be interpreted rather cautiously because of the low number of animals $(\mathrm{n}=$ 8) that were used in the present study. Unexpectedly, we found only minor effects of extrusion processing on ruminal protein utilization and postruminal $\mathrm{N}$ flow; however, extrusion processing appeared to improve $\mathrm{N}$ efficiency based on decreased plasma urea-N and MUN levels. Milk production and milk protein yield were increased when feeding WDDGS-peas compared with WDDGS-CM, a response that can be partly attributed to greater nutrient supply due to increased total-tract digestibilities of $\mathrm{CP}$ and starch.

\section{ACKNOWLEDGMENTS}

The authors thank Marlene Fehr and staff of the Greenbrae Dairy Research Facility, University of Saskatchewan, for animal care and excellent technical assistance. The authors also thank $\mathrm{O}$ and $\mathrm{T}$ Farms (Regina, SK, Canada) for processing the WDDGSPeas and WDDGS-CM supplements. This research 
was supported by the Government of Saskatchewan's Agriculture Development Fund (ADF, Regina, SK, Canada) and Agriculture and Agri-Food Canada (Agriculture BioProducts Innovation Program, Ottawa, ON, Canada).

\section{REFERENCES}

Abdelqader, M. M., and M. Oba. 2012. Lactation performance of dairy cows fed increasing concentrations of wheat dried distillers grains with solubles. J. Dairy Sci. 95:3894-3904.

Aldrich, C. G., N. R. Merchen, D. R. Nelson, and J. A. Barmore. 1995. The effects of roasting temperature applied to whole soybeans on site of digestion by steers: II Protein and amino acid digestion. J. Anim. Sci. 73:2131-2140.

Allen, M. S. 2000. Effects of diet on short-term regulation of feed intake by lactating dairy cows. J. Dairy Sci. 83:1598-1624.

AOAC. 1990. Official Methods of Analysis. 15th ed. Assoc. Off. Anal. Chem., Arlington, VA.

Bauman, D. E., and J. M. Griinari. 2001. Regulation and nutritional manipulation of milk fat: Low-fat milk syndrome. Livest. Prod. Sci. 70:15-29.

Baumgard, L. H., B. A. Corl, D. A. Dwyer, A. Saebo, and D. E. Bauman. 2000. Identification of the conjugated linoleic acid isomer that inhibits milk fat synthesis. Am. J. Physiol. Regul. Integr. Comp. Physiol. 278:R179-R184.

Benchaar, C., M. Vernay, C. Bayourthe, and R. Moncoulon. 1994. Effects of extrusion of whole horse beans on protein digestion and amino acid absorption in dairy cows. J. Dairy Sci. 77:1360-1371.

Binnerts, W. T., A. T. van't Klooster, and A. M. Frens. 1968. Soluble chromium indicator measure by atomic absorption in digestion experiments. Vet. Rec. 82:470-476.

Boila, R. J., and J. R. Ingalls. 1994. The post-ruminal digestion of dry matter, nitrogen and amino acids in wheat-based distillers dried grains and canola meal. Anim. Feed Sci. Technol. 49:173-188.

Brito, A. F., G. A. Broderick, and S. M. Reynal. 2006. Effect of varying dietary ratios of alfalfa silage to corn silage on omasal flow and microbial protein synthesis in dairy cows. J. Dairy Sci. 89:39393953.

Brito, A. F., G. F. Tremblay, H. Lapierre, A. Bertrand, Y. Castonguay, G. Bélanger, R. Michaund, C. Benchaar, D. R. Ouellet, and R. Berthiaume. 2009. Alfalfa cut at sundown and harvested as baleage increases bacterial protein synthesis in late-lactation dairy cows. J. Dairy Sci. 92:1092-1107.

Broderick, G. A. 2003. Effects of varying dietary protein and energy levels on the production of lactating dairy cows. J. Dairy Sci. $86: 1370-1381$

Broderick, G. A., A. F. Brito, and J. J. Olmos Colmonero. 2007. Effects of feeding formate-treated alfalfa silage or red clover silage on the production of lactating dairy cows. J. Dairy Sci. 90:1378-1391.

Broderick, G. A., and J. H. Kang. 1980. Automated and simultaneous determination of ammonia and total amino acids in ruminal fluids and in vitro media. J. Dairy Sci. 63:64-75.

Canadian Council on Animal Care. 1993. Guide to the Care and Use of Experimental Animals. Vol. 1. CCAC, Ottawa, Ontario, Canada.

Chapoutot, P., and D. Sauvant. 1997. Nutritive value of raw and extruded pea-rapeseed blends for ruminants. Anim. Feed Sci. Technol. 65:59-77.

Chibisa, G. E., D. A. Christensen, and T. Mutsvangwa. 2012. Effect of replacing canola meal as the major protein source with wheat distillers grains with solubles on ruminal function, microbial protein synthesis, omasal flow, and milk production in cows. J. Dairy Sci. 95:824-841.

Chibisa, G. E., and T. Mutsvangwa. 2013. Effects of feeding wheat or corn-wheat dried distillers grains with solubles in low- or highcrude protein diets on ruminal function, omasal nutrient flows, urea-N recycling, and performance in cows. J. Dairy Sci. 96:65506563 .
Chouinard, P. Y., V. Girard, and G. J. Brisson. 1997. Performance and profiles of milk fatty acids of cows fed full fat, heat-treated soybeans using various processing methods. J. Dairy Sci. 80:334-342.

Colmenero, J. J., and G. A. Broderick. 2006b. Effect of dietary crude protein concentration on milk production and nitrogen utilization in lactating dairy cows. J. Dairy Sci. 89:1704-1712.

Corbett, R. R., E. K. Okine, and L. A. Goonewardene. 1995. Effects of feeding peas to high-producing dairy cows. Can. J. Anim. Sci. 75:625-629.

Deacon, M. A., G. De Boer, and J. J. Kennelly. 1988. Influence of JetSploding and extrusion on ruminal and intestinal disappearance of canola and soybeans. J. Dairy Sci. 71:745-753.

Erwin, E. S., G. J. Marco, and E. M. Emery. 1961. Volatile fatty acids analysis of blood and rumen fluid by gas chromatography. J. Dairy Sci. 44:1768-1776.

Focant, M., A. Van Hoecke, and M. Vanbelle. 1990. The effect of two heat treatments (steam flaking and extrusion) on the digestion of Pisum sativum in the stomachs of heifers. Anim. Feed Sci. Technol. 28:303-313

France, J., and R. C. Siddons. 1986. Determination of digesta flow by continuous marker infusion. J. Theor. Biol. 121:105-120.

Gonthier, C., A. F. Mustafa, R. Berthiaume, H. V. Petit, R. Martineau, and D. R. Ouellet. 2004. Effects of feeding micronized and extruded flaxseed on ruminal fermentation and nutrient utilization by dairy cows. J. Dairy Sci. 87:1854-1863.

Gonthier, C., A. F. Mustafa, D. R. Ouellet, P. Y. Chouinard, R. Berthiaume, and H. V. Petit. 2005. Feeding micronized and extruded flaxseed to dairy cows: Effects on blood parameters and milk fatty acid composition. J. Dairy Sci. 88:748-756.

Hickling, D. 2008. Maximized utilization of canola co-products in the livestock industry. Pages 3-14 in Proc. 29th Western Nutrition Conference. Edmonton, Alberta, Canada. University of Alberta, Edmonton, AB, Canada.

Huhtanen, P., P. G. Brotz, and L. D. Satter. 1997. Omasal sampling technique for assessing fermentative digestion in the forestomach of dairy cows. J. Anim. Sci. 75:1380-1392.

Huhtanen, P., K. Kaustell, and S. Jaakkola. 1994. The use of internal markers to predict total digesitibility and duodenal flow of nutrients in cattle given six different diets. Anim. Feed Sci. Technol. 48:211-227.

Imran, M., F. M. Anjum, M. S. Butt, and M. A. Sheikh. 2014. Influence of extrusion processing on tannin reduction and oil loss in flaxseed (Linum usitatissimum L.) meal. J. Food Process. Preserv. 38:622-629.

Jenkins, T. C., and M. A. McGuire. 2006. Major advances in nutrition: Impact on milk composition. J. Dairy Sci. 89:1302-1310.

Jones, R. A., A. F. Mustafa, D. A. Christensen, and J. J. McKinnon. 2001. Effects of untreated and heat-treated canola presscake on milk yield and composition of dairy cows. Anim. Feed Sci. Technol. 89:97-111.

Khorasani, G. R., E. K. Okine, R. R. Corbett, and J. J. Kennelly. 2001. Nutritive value of peas for lactating dairy cattle. Can. J. Anim. Sci. 81:541-551.

Kleinschmit, D. H., J. L. Anderson, D. J. Schingoethe, K. F. Kalscheur, and A. R. Hippen. 2007. Ruminal and intestinal degradability of distillers grains plus solubles varies by source. J. Dairy Sci. 90:2909-2918.

Littell, R. C., G. A. Milliken, W. W. Stroup, R. D. Wolfinger, and O. Schabenberger. 2006. SAS for Mixed Models. 2nd ed. SAS Institute Inc., Cary, NC.

Marsh, W. H., B. Fingerhunt, and E. Kirsch. 1957. Determination of urea $\mathrm{N}$ with the diacetyl method and an automatic dialyzing apparatus. Am. J. Clin. Pathol. 28:681-688.

Masoero, F., M. Moschini, G. Fusconi, and G. Piva. 2006. Raw, extruded and expanded pea (Pisum sativum) in dairy cow diets. Ital. J. Anim. Sci. 5:237-247.

Maxin, G., D. R. Ouellet, and H. Lapierre. 2013a. Effect of substitution of soybean meal by canola meal or distillers grains in dairy rations on amino acid and glucose availability. J. Dairy Sci. 96:7806-7817.

Maxin, G., D. R. Ouellet, and H. Lapierre. 2013b. Ruminal degradability of dry matter, crude protein, and amino acids in soybean 
meal, canola meal, corn, and wheat dried distillers grains. J. Dairy Sci. 96:5151-5160.

Meyer, M. J., J. E. Shirley, E. C. Titgemeyer, A. F. Park, and M. J. VanBaale. 2001. Effect of mechanical processing and fat removal on the nutritive value of cottonseed for lactating dairy cows. J. Dairy Sci. 84:2503-2514.

Moallem, U. 2009. The effects of extruded flaxseed supplementation to high yielding dairy cows on milk production and milk fatty acid composition. Anim. Feed Sci. Technol. 152:232-242.

Mulrooney, C. N., D. J. Schingoethe, K. F. Kalscheur, and A. R. Hippen. 2009. Canola meal replacing distillers grains with solubles for lactating dairy cows. J. Dairy Sci. 92:5669-5676.

Mustafa, A. F., P. Y. Chouinard, and D. A. Christensen. 2003. Effects of feeding micronized flaxseed on yield and composition of milk from Holstein cows. J. Sci. Food Agric. 83:920-926.

NRC. 2001. Nutrient Requirements of Dairy Cows. 7th rev. ed. Natl. Acad. Sci., Washington, DC.

Neves, C. A., W. B. R. dos Santos, G. T. D. Santos, D. C. da Silva, C. C. Jobim, F. S. Santos, J. V. Visentainer, and H. V. Petit. 2009. Production performance and milk composition of dairy cows fed extruded canola seeds treated with or without lignosulfonate. Anim. Feed Sci. Technol. 154:83-92.

Neveu, C., B. Baurhoo, and A. Mustafa. 2013. Effect of feeding extruded flaxseed with different forage:concentrate ratios on the performance of dairy cows. J. Dairy Sci. 96:3886-3894.

Nuez-Ortín, W. G., and P. Yu. 2010. Estimation of ruminal and intestinal digestion profiles, hourly effective degradation ratio and potential $\mathrm{N}$ to energy synchronization of co-products from bioethanol processing. J. Sci. Food Agric. 90:2058-2067.

Orias, F., C. G. Aldrich, J. C. Elizalde, L. L. Bauer, and N. R. Merchen. 2002. The effects of dry extrusion temperature of whole soybeans on digestion of protein and amino acids by steers. J. Anim. Sci. 80:2493-2501.

Pena, F., H. Tagari, and L. D. Satter. 1986. The effect of heat treatment of whole cottonseed on the site and extent of protein digestion in dairy cows. J. Anim. Sci. 62:1423-1433.

Petit, H. V., R. Rioux, and D. R. Ouellet. 1997. Milk production and intake of lactating cows fed raw or extruded peas. J. Dairy Sci. 80:3377-3385.

Petit, H. V. 2010. Review: Feed intake, milk production and milk composition of dairy cows fed flaxseed. Can. J. Anim. Sci. 90:115-127.

Reynal, S. M., G. A. Broderick, and C. Bearzi. 2005. Comparison of four markers for quantifying microbial protein flow from the rumen of lactating dairy cows. J. Dairy Sci. 88:4065-4082.

SAS Institute. 2004. SAS/STAT 9.1 User's Guide. SAS Institute Inc., Cary, NC.

Satter, L. D., and L. L. Slyter. 1974. Effect of ammonia concentration on rumen microbial protein production in vitro. Br. J. Nutr. 32:199-208.

Schingoethe, D. J., K. F. Kalscheur, A. R. Hippen, and A. D. Garcia. 2009. Invited review: The use of distillers products in dairy cattle diets. J. Dairy Sci. 92:5802-5813.
Scott, T. A., D. K. Combs, and R. R. Grummer. 1991. Effects of roasting, extrusion, and particle size on the feeding value of soybeans for dairy cows. J. Dairy Sci. 74:2555-2562.

Siddons, R. C., J. Paradine, D. E. Beever, and P. R. Cornell. 1985. Ytterbium acetate as a particulate-phase digesta-flow marker. Br. J. Nutr. 54:509-519.

Solanas, E. M., C. Castrillo, M. Jover, and A. de Vega. 2008. Effect of extrusion on in situ ruminal protein degradability and in vitro digestibility of undegraded protein from different feedstuffs. J. Sci. Food Agric. 88:2589-2597.

Sterk, A., B. E. O. Johansson, H. Z. H. Taweel, M. Murphy, A. M. Van Vuuren, W. H. Hendriks, and J. Dijkstra. 2011. Effects of forage type, forage to concentrate ratio, and crushed linseed supplementation on milk fatty acid profile in lactating dairy cows. J. Dairy Sci. 94:6078-6091.

Stern, M. D., K. A. Santos, and L. D. Satter. 1985. Protein degradation in rumen and amino acid absorption in small intestine of lactating dairy cattle fed heat-treated whole soybeans. J. Dairy Sci. 68:45-56.

Sun, Y., and M. Oba. 2014. Effects of feeding a high-fiber byproduct feedstuff as a substitute for barley grain on rumen fermentation and productivity of dairy cows in early lactation. J. Dairy Sci. 97:1594-1602.

Svihus, B., A. K. Uhlen, and O. M. Harstad. 2005. Effect of starch granule structure, associated components and processing on nutritive value of cereal starch: A review. Anim. Feed Sci. Technol. 122:303-320.

Trinder, P. 1969. Determination of blood glucose using an oxidaseperoxidase system with a non-carcinogenic chromogen. J. Clin. Pathol. 22:158-161.

Udén, P., P. E. Colucci, and P. J. Van Soest. 1980. Investigation of chromium, cerium and cobalt as markers in digesta: Rate of passage studies. J. Sci. Food Agric. 31:625-632.

Van Soest, P. J., J. B. Robertson, and B. A. Lewis. 1991. Methods for dietary fiber, neutral detergent fiber and non-starch polysaccharide in relation to animal nutrition. J. Dairy Sci. 74:3583-3597.

Vicente, F., A. Sarraseca, A. de Vega, and J. A. Guada. 2004. Performance of several $\mathrm{Cr}$ and $\mathrm{Yb}$ analytical techniques applied to samples of different biological origin (digesta or faeces). J. Sci. Food Agric. 84:2035-2040.

Walhain, P., M. Foucart, and A. Théwis. 1992. Influence of extrusion on ruminal and intestinal disappearance in sacco of pea (Pisum sativum) proteins and starch. Anim. Feed Sci. Technol. 38:43-55.

Wang, Y., T. A. McAllister, M. D. Pickard, Z. Xu, L. M. Rode, and K.-J. Cheng. 1999. Effect of micronizing full fat canola seed on amino acid disappearance in the gastrointestinal tract on dairy cows. J. Dairy Sci. 82:537-544.

Zebeli, Q., J. Dijkstra, M. Tafaj, H. Steigass, B. N. Ametaj, and W. Drochner. 2008. Modeling the adequacy of dietary fiber in dairy cows based on the response of ruminal $\mathrm{pH}$ and milk fat production to composition of the diet. J. Dairy Sci. 91:2046-2066. 